\title{
Fishing effects and life history traits: a case study comparing tropical versus temperate tunas
}

\author{
Jean-Marc Fromentin ${ }^{*}$ a and Alain Fonteneau ${ }^{b}$
}

\author{
a : Institut Français de Recherche pour l'Exploitation de la MER (IFREMER), Département des Ressources \\ Halieutiques, 1 rue Jean Vilar, BP 171, 34203 Sète Cedex, France \\ b : Institut de Recherche pour le Développement (IRD), Laboratoire Halieutique et Ecosystème Aquatique, BP \\ 5045, 34032 Montpellier, France \\ *: Corresponding author : Tel.: +33-467-467-808; fax: +33-467-747-090; email: jean.marc.fromentin@ifremer.fr
}

\begin{abstract}
:
This study aims to test whether exploitation affects tunas and tuna-like species displaying contrasting life history traits similarly. We first collected information on life history of 10 commercial Atlantic species and then compared this information using multivariate analysis. On one hand, tropical tunas are characterised by small to medium size, rapid growth, early age-at-maturity, long spawning duration and short life span. These species, therefore, display a rapid turnover, characteristic of $r$-selected species. On the other hand, temperate tunas display differing life history traits, i.e., large size, slow growth, late age-at-maturity, short spawning duration and long life span. The turnover of these species is slow and present characteristics similar to ' $K$-selected' species (with a conservative strategy adapted to a colder and more variable environment). We, then, selected the two tuna species displaying the most contrasting life histories, i.e., skipjack (SKJ) and bluefin tuna (BFT), and investigated their respective responses to various levels of exploitation, using simulation modelling. If fishing activity starts at age 1 (a situation which is close to the actual exploitation pattern), differences in life history traits make the BFT population much more fragile to exploitation and less productive than SKJ. However, if the fisheries only target adults, both SKJ and BFT populations are able to sustain high $F$. Spawning stocks and yields of BFT also display conspicuous long-term fluctuations, resulting from the combination of year-to-year variations in the recruitment and a long life span. This variability makes it difficult to detect overfishing or depletion risks in the BFT population. Because of its short life span, SKJ does not display such long-term variations in its SSB. Our simulations also showed that current management measures based on a minimum size limit are much more critical for BFT than SKJ. This difference stresses the importance of taking account of differences in life history traits into management measures.
\end{abstract}

Keywords: Bluefin tuna; Skipjack; Simulation modelling; Long-term fluctuations; Fishing; Sustainability; Management measures 


\section{Introduction}

Longhurst (1998) recently hypothesised that differences in life history traits might explain why warm-water species, such as yellowfin tuna, could sustain an industrial fishery, if managed through standard stock assessment procedures, whereas cold-water species, such as cod, could not. This hypothesis is in agreement with recent studies that showed how the effects of exploitation were dependent on the life history traits of the fish populations. Species displaying a late age-at-maturity, large size, slow growth and low rate of potential population increase, appeared more vulnerable to exploitation and declined more in abundance than others (Jennings et al., 1998; 1999). As a consequence, Greenstreet et al. (1999) showed that the exploitation of the whole North Sea groundfish assemblage lead to a decrease in species diversity and abundance as well as to a shift towards an assemblage dominated by smaller fish; a result that could be observed in other exploited fish assemblages.

In view of these studies, it was of interest to test whether exploitation affects tunas and tuna-like species displaying contrasting life history traits similarly. Industrial fisheries have exploited several Atlantic tunas and tuna-like species since the second world war (and even before for the Atlantic bluefin tuna and albacore). Tunas are frequently considered to be typical tropical and warm-water species. While most of the commercially important tunas, such as skipjack, bigeye tuna or yellowfin tuna, do belong to this group, other tunas are temperate-water species and can be even found in cold waters. Latitudinal distribution of the East Atlantic bluefin tuna, for instance, historically ranged from the Canary Islands to the North of Norway (Mather et al., 1995; Tiews, 1978). We, thus, collected information on life history traits of 10 commercial tunas and tuna-like species, related to spawning, growth, maturation and life span. Using multivariate analysis, we compared life history traits among these species. We, then, selected tunas displaying the most contrasting life histories, skipjack and bluefin tuna, to investigate their respective responses to various levels of exploitation, using simulation modelling. 
First part: Comparison of life history traits of tuna and tuna-like species

\section{Data}

When accurate information was available, data on life history traits of tunas and tuna-like species were collected from scientific literature. Otherwise, information was derived from catch-at-age and tagging data (see below). Among life history traits, we selected biological information on:

(i) The spawning duration (i.e., the number of months per year during which spawning usually occurs) was collected from the literature.

(ii) Length, weight and age at maturity was also collected from the literature. These factors can be differently defined but we used the most general definition, i.e., the age, length and weight at which $50 \%$ of the individuals are mature and able to reproduce. When only one or two of these three factors were available, we deduced others from growth curves and/or the length-weight relationships.

(iii) Maximum length, weight and age were estimated from catch-at-age and tagging data because published information on life span is rare and sometimes difficult to validate. To avoid any effect of over-exploitation on our estimates, we restricted calculations to the periods for which industrial fishing was at its beginning. For each species, we selected the fishery that used to catch the biggest and oldest individuals, e.g., the Japanese long liners for ALB, BET, BFT, SAI and SBF. Maximum length and weight were computed from the catch-at-age data, using the cumulated histograms of the catches versus the length or weight. Maximum length and weight were stated as the value corresponding to $99 \%$ of the distribution. Maximum age was computed from tagging data and defined as the longest observed duration between a mark and a recapture, plus the age of the fish when marked (suspect or incomplete information was not considered).

(iv) Growth was computed as: $\frac{\left(\frac{\text { Length }- \text { at }- \text { maturity }}{\text { Maximum }- \text { length }}\right) * 100}{\text { Age }- \text { at - maturity }}$. This index corresponds to the mean juvenile growth scaled by the maximum length. We did not deduce growth and maximum length from the parameters $K$ and $L_{\infty}$ of the von Bertalanffy growth equation (see Jennings et al., 1998; 1999), because of large differences between various estimates (for yellowfin tuna, $K$ ranged from 
0.28 to 0.86 depending on the authors and for skipjack from 0.38 in equatorial area to 2.08 in tropical area, Cayré et al., 1988).

(v)Tunas are known to be sensitive to temperature but some species are able to support cold waters because of a more efficient thermoregulation (Mather et al., 1995; Bard et al., 1998; Cayré et al., 1988). Minimal sea surface temperature (SST) is, therefore, a discriminate physiological variable between tunas. We estimated the minimum tolerated SST by comparing the means geographical distribution of the quarterly catches with the quarterly SST patterns (using a $5^{\text {th }}$ degree square). The minimal SST being set as the limit of SST above which 95\% of the catches were made.

We did not include information on fecundity because of a lack of data for several species and important spatial and seasonal variations for others (Cayré et al., 1988). Because of important differences between populations of Atlantic tunas, the present study only refers to the life history traits of the Northeast Atlantic populations. According to the available information on biology, we finally selected a pool of 10 species (Table 1). Skipjack (SKJ, Katsuwonus pelamis), Atlantic little tuna (LTA, Euthynnus alletteratus) and yellowfin tuna (YFT, Thunnus albacares) are typical tropical tunas, which are mainly concentrated from $20^{\circ} \mathrm{N}$ to $10^{\circ} \mathrm{S}$ for the two first species and from $35^{\circ} \mathrm{N}$ to $20^{\circ} \mathrm{S}$ for the latter. Bigeye tuna (BET, Thunnus obesus), Atlantic sailfish (SAI, Istiophorus albicans) and Atlantic white marlin (WHM, Tetrapturus albidus) are subtropical species, having a wider distribution than tropical ones (from $50^{\circ} \mathrm{N}$ to $40^{\circ} \mathrm{S}$ ). Albacore (ALB, Thunnus alalunga) and swordfish (SWO, Xiphias gladius) are often considered as sub-tropical species, but they are also common in temperate waters. Because of the strong sexual dimorphism in SWO populations, only information on females was retained. Bluefin tuna (BFT, Thunnus thynnus thynnus) and southern bluefin tuna (SBF, Thunnus maccoyii) are mainly temperate tunas, usually found from $35^{\circ} \mathrm{N}$ to $60^{\circ} \mathrm{N}$ and from $25^{\circ} \mathrm{S}$ to $50^{\circ} \mathrm{S}$ for $\mathrm{BFT}$ and $\mathrm{SBF}$, respectively. Most of the tunas are highly migratory species. However, SBF and BFT probably perform the greatest migrations, since they reproduce in warm waters (the Indonesian waters, South of Java, for SBF and the Western Mediterranean Sea and the Gulf of Mexico for BFT) but mainly feed in temperate and cold waters (Mather et al., 1995). 


\section{Numerical analysis: The Principal Component Analysis (PCA)}

PCA summarises into a few dimensions (i.e., the principal axes) the variability of a given number of descriptors and provides the variance explained by each principal axis (e.g., Legendre and Legendre, 1998). A PCA was performed, using a correlation matrix, on the life history traits table (Table 1), using the species as objects and life history parameters as descriptors. Our purpose is, here, to test the hypothesis of opposite life history traits between temperate and tropical species on tunas and tunalike species. If this hypothesis is valid, then the first axes of the PCA should clearly distinguish tropical and temperate tunas and a high percentage of variance should be explained by the first principal axis. To display the results, we used the biplot representation (Gabriel, 1971), which allows projecting both the descriptors and the objects in the space of the principal axes, so that it is graphically possible to interpret the links between descriptors and objects. Calculations were made using S-Plus 4.5 (S-Plus, 1997).

\section{Results}

Because several descriptors such as length, weight and age-at-maturity were redundant and highly correlated, the PCA was restricted to the 5 descriptors which maximised the variance upon axis 1 , i.e., length at maturity, maximum age, juvenile growth, spawning duration and minimal SST. The two first axes of the PCA encompassed more than $90 \%$ of the total variance. The first axis, which alone summarised $74 \%$ of the total variance, clearly opposed growth and spawning duration (and secondarily minimal SST) on the one hand against maximum age and length at maturity on the other (Fig. 1). Along this axis, the two typical temperate species, BFT and SBF as well as SWO, were opposed to two of the three tropical species, SKJ and LTA (Fig. 1). Axis 1 clearly distinguished between tunas, which grow and mature quickly, spawn all year long, do not reach a long size and live in warm waters, and tunas that grow slowly, only spawn 1 to 3 months per year, mature lately, reach a large size and can live in cold waters, i.e., a clear divergence between tropical and temperate tunas. 
The subtropical species (WHM, SAI, BET) as well as ALB and YFT, are positioned in between. YFT, the third typical tropical species, is closer to SKJ and LTA than to BFT and SBF (Fig. 1).

The second axis of the PCA, which corresponds to $16.1 \%$ of the total variance (4.5 times less than the first axis), is mainly determined by minimal SST (Fig. 1). It opposes SBF, BFT (and secondarily ALB) to SAI, WHM (and secondarily SWO), the former being able to sustain colder waters than the latter. Among species displaying temperate life histories, axis 2, distinguishes between the two purely temperate species (BFT and SBF) and SWO (Fig. 1).

\section{Second part: Impact of exploitation on tropical versus temperate tunas}

The life history traits of tropical and temperate tunas and tuna-like species are very different. The former, which live in a warmer and rather stable environment, are characterised by a rapid growth, small size, early age-at-maturity, short life span and spawn mostly all the year; all these properties leading to a rapid turnover of the population. In contrast, temperate tunas, which live in a colder and more variable environment, have a shorter spawning period and display a rather low turnover of their population. Therefore, we selected the two most differing species, i.e., skipjack (SKJ) and bluefin tuna (BFT), to test whether tropical tunas could support higher levels of fishing mortality than temperate tunas because of their rapid turnover and stable recruitment.

\section{Simulation modelling}

Our purpose is to compare fishing effects on species displaying contrasting life histories. One approach would have been to use classical deterministic models, such as yields-per-recruit analysis or surplus modelling (e.g., Gulland, 1977; Hilborn and Walters, 1992). However, these models imply several assumptions, such as constant recruitment, stable fishing patterns through time, etc.., which are known to be violated for both BFT and SKJ (Anonymous, 1999; Fonteneau, 1986; Fromentin, 1999; Pallares et al., 1998). We, therefore, decided to build a simulation model, which was better 
adapted to our exploratory approach and also allowed some flexibility, especially to investigate the effects of variation in recruitment.

The simulation model is based on the fundamental equation of fish population dynamics:

$$
N_{a, t}=N_{a-1, t-1-1} e^{-Z t},
$$

where, $N_{a, t}$ is the number of fish of age (a) at time (t), and $\mathrm{Z}$ the total mortality from age (a-1) to age (a). $\mathrm{Z}=\mathrm{M}+\mathrm{F}$, with $\mathrm{M}$ being the natural mortality and, $\mathrm{F}$ the fishing mortality. As density-dependent processes have not been clearly established for tunas, we did not introduce density-dependent mortality for vulnerable ages (juveniles) in the model (Fromentin et al., in press; Myers and Cadigan, 1993). The main life history traits of both species were stated in the model as follows:

- SKJ: monthly spawning (12 cohorts per year), life span of 4.5 years, maturity at 1.5 years and natural mortality stated at 0.8 for all the ages $(\mathrm{Au}, 1986)$. Mean weights spread from $1 \mathrm{~kg}$ at age 1 to $7 \mathrm{~kg}$ at age 4.5 (Cayré et al., 1988).

- BFT: yearly spawning (1 cohort per year), life span of 20 years, maturity at 4.5 years. The natural mortality of East Atlantic BFT is poorly known. The closest estimates are probably those obtained from tagging experiments on the Southern bluefin tuna, showing that $\mathrm{M}$ is age-specific and about 5 times higher for juveniles (0.49) than adults (0.1, see Anonymous 1997). Following the last stock assessment of the East Atlantic BFT (Anonymous, 1999), we have selected these M estimates. Mean weights spread from $4 \mathrm{~kg}$ at age 1 to $400 \mathrm{~kg}$ at age 20 (Anonymous, 1997).

For both species, we assumed a Beverton and Holt stock/recruitment relationship (Beverton and Holt, 1957), which implies density dependence in per capita recruitment. The general form of this equation may be written as follows (Cushing, 1995):

$$
R=\operatorname{aSSB}\left(\frac{S S B}{K}\right)
$$

where $R$ is recruitment in numbers, $a$ is the slope at the origin, SSB is the spawning stock biomass in tonnes and $\mathrm{K}$ is the threshold biomass. We have chosen a Beverton and Holt model because it is 
currently used within the 'ICCAT BFT working group'. This choice could appear arbitrary but simulations conducted with a Ricker stock/recruitment model (Ricker, 1954) lead to equivalent results. A deterministic stock/recruitment relationship was chosen instead of a time series approach, to model, in a simple way, 'recruitment overfishing' (i.e., collapse of the recruitment due to a very low spawning stock biomass). Because of the effects of year-to-year fluctuations in environmental conditions and/or predation on the recruitment (e.g., Cushing, 1995; Hjort, 1914; May, 1974), we included a random noise component, $\varepsilon$, so that:

$$
R=\operatorname{aSSB} f\left(\frac{S S B}{K}\right) \cdot \varepsilon
$$

where, $\varepsilon$, is Gamma distributed (Engen and Lande, 1996) with mean and standard deviation equal to 1 (i.e., moderate variance). Although tropical tunas live and reproduce in warm waters which are generally assumed to be more stable than temperate ones (see Discussion), we used the same forcing function for both species. It would have been simple to consider a lower level of random noise for SKJ than BFT, but we preferred not to do so in order to facilitate the comparison of the results. Our simulations, therefore, could have over-estimated the noise in the SKJ recruitment, but this feature did not affect the conclusions. Furthermore, the way in which the spawning process was modelled implies that the year-class strength for SKJ is less variable than for BFT. SKJ was indeed modelled to spawn every month, so that its population dynamics was run on a monthly basis. As the comparison between SKJ and BFT was made on an annual basis, the annual recruitment for SKJ was computed as the sum of the 12 spawning events of a given year, whereas the annual recruitment of BFT resulted from a single spawning.

Our aim is to test whether SKJ could support higher levels of fishing mortality than BFT, independently of their respective natural mortalities. Therefore, we considered equal values of $\mathrm{F}$ for both species, which implies that BFT supports higher F/M than SKJ (see also Discussion). We built three different scenarios (Fig. 2): 
- A constant scenario, with annual F equal to 0.5 (approximately equal to $0.625 \mathrm{M}$ for SKJ and $1 \mathrm{M}$ to $5 \mathrm{M}$ for BFT).

- A step-by-step scenario, with annual F equal to 0.2, 0.5 and 0.8 during three equal periods (i.e., equal to $0.25 \mathrm{M}$ to $1 \mathrm{M}$ for $\mathrm{SKJ}$ and $0.4 \mathrm{M}$ to $8 \mathrm{M}$ for BFT).

- An exponential scenario, with annual F going from 0.1 to 1.6 (i.e., equal to $0.125 \mathrm{M}$ to $2 \mathrm{M}$ for SKJ and $0.2 \mathrm{M}$ to $16 \mathrm{M}$ for BFT).

Simulations were run over 200 years, after a transition period of 50 years that allows a steady state to be reached. The equilibrium value was set at a spawning stock biomass equal to 1 million tonnes for both species. We first considered an age-specific selectivity patterns equal for all the ages, $\mathrm{F}_{\text {age } 1}=$

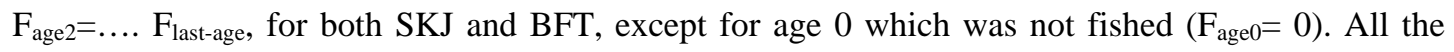
simulations were then repeated considering another age-specific selectivity pattern in which only adults were caught for both species ( $\mathrm{F}=0$ until age 1.5 and age 4 for SKJ and BFT, respectively; see Discussion for considerations regarding a realistic age-specific selectivity pattern).

Simulations were also made by adding white noise (normally distributed) to $\mathrm{F}$ in order to take account for random variations in catchability or in fishing selectivity. These results are not shown because they did not bring any additional information. For each scenario and each species, the runs were repeated one hundred times to compute a mean of the main statistics, summarised in Tables 2 and 3. Simulations were operated using Matlab 5.3 (Matlab, 1999).

\section{Results}

Population dynamics without fishing

For a SSB balanced at 1 million tonnes, the numbers of yearly recruits (age 0) were, for SKJ and BFT, about 663 millions and 4 millions and the numbers of spawners about 372 millions and 6.8 millions, respectively (i.e., 162 and 55 times higher for SKJ than for BFT, Table 2). These 
differences mainly resulted from the early age-at-maturity of SKJ, as well as the large average weight of the BFT spawners (200 kg for BFT against $3 \mathrm{~kg}$ for SKJ ).

Adding the same level of noise (Gamma distributed) to SKJ and BFT recruitment lead to pseudocyclic fluctuations in SSB (Fig. 3), which result from the autocovariance generated by the autoregressive processes. In statistical terms, this corresponds to the moving average term in the autoregressive time series modelling (Box and Jenkins, 1976; Wei, 1990). The autocovariance is related to the numbers of age classes, so that the main period of these cycles depends on the life span of the species, i.e., $~ 5 \mathrm{yr}$ for SKJ and $\sim 20$ yr or more for BFT (Fig. 3). Coefficients of variation (CV, the standard deviation scaled by the mean, Sokal and Rohlf, 1995) indicated that BFT annual recruitment was, on average, about 3 to 4 times more variable than for SKJ one (Fig. 4, Table 2). This difference simply reflects the way the spawning process is modelled: 12 times per year for SKJ against once a year for BFT, so that the annual recruitment for SKJ (the sum of the 12 recruitments of a given year) is automatically less variable. Variations in SSB were low, but slightly more important for BFT because of the long-term cycles.

\section{Constant fishing mortality scenario}

Adding a constant fishing mortality of 0.5 did not change the mean and $\mathrm{CV}$ of recruitment for either species (Table 2). However, the SSB fell to about 527100 and 32800 tonnes for SKJ and BFT respectively, i.e., about 2 and 30 times lower than previously (Table 2). Constant $\mathrm{F}$ also induced a 1.5-fold and a 15-fold decrease in the number of SKJ and BFT spawners. The decrease in SSB and numbers of spawners was, thus, much stronger for BFT than SKJ. Note that the decline was steeper in the SSB than in the number of spawners, especially for BFT (because of the considerable weight of the oldest spawners). The CV for the SKJ SSB increased slightly, whereas the one for BFT rose significantly (Table 2). Adding a constant F has, thus, also induced a higher variability in the BFT SSB, probably because of a lower mean which make the year-to-year fluctuations in recruitment more apparent in the SSB (Fig. 4). As in the previous scenario, the BFT SSB displayed conspicuous, 
although less regular, pseudo-cycles (Fig. 4), resulting from the combination of variations in the recruitment and the long life span (see above).

Total yields were about 242800 and 27000 tonnes for SKJ and BFT respectively, i.e., 9 times higher for SKJ (Table 2). The BFT yields were of the same magnitude as its SSB, whereas those of SKJ were about 2 times lower (Table 2). SKJ thus appeared clearly more productive than BFT. Fluctuations in yields of both species mainly reflected those of the SSB and were higher for BFT than SKJ (Table 2, Fig. 4). Although F remained constant during all the period, the BFT yields displayed conspicuous pseudo-cycles (Fig. 4), with a periodicity of around 20 years of high catches ( 40-50 000 tonnes) and low catches ( 10-20 000 tonnes). Such fluctuations did not occur in the yields of SKJ.

\section{Step-by-step fishing mortality scenario}

From the beginning to the end of the fishing period, the SSB of BFT decreased from about 200000 to 5000 tonnes (mean at 78000 tonnes), whereas the SSB of SKJ only decreased from about 700000 to 400000 tonnes (mean at 560000 tonnes, Fig. 5 and Table 2). The SKJ SSB was still much higher than that of BFT (80 times higher at the end of the fishing period). Total yields of BFT decreased from 50000 to 15000 tonnes (mean at 29 000 tonnes, Table 2) from the beginning to the end of the fishing period, but the presence of pseudo-cycles partially blurred this decline (Fig. 5, the CV of the yields was still high, Table 2). At the end of the fishing period, the BFT yields were 3 times higher than its SSB (Table 2). All together, this indicated that the simulated BFT population had reached its limits of sustainability and was clearly overexploited. Conversely, the yields of SKJ increased from 130000 tonnes to 290000 tonnes (mean at 225 000 tonnes, Fig. 5 and Table 2); a level still largely below the SSB value. SKJ was, thus, again much more productive than BFT and able to sustain fishing mortality equal to 0.8 . Note, however, that the SKJ yields were of similar magnitude for $\mathrm{F}=0.5$ and $\mathrm{F}=0.8$, indicating that the $\mathrm{F}_{\max }$ could have been exceeded. 


\section{Exponential fishing mortality scenario}

This scenario first lead to recruitment overfishing (Fig. 6, after time $\mathrm{t}=200$ ), then rapidly to the collapse of the simulated BFT population (Fig. 6, after time $\mathrm{t}=225$ ). The BFT yields displayed a crash in parallel to the occurrence of the recruitment overfishing (Fig. 6). The conspicuous pseudo cycles in the yields, resulting from variations into recruitment and the long life span, have, however, blurred the exponential decline and made the crash of the yields sudden and abrupt (Fig. 6). Because of the numerous age-classes, the BFT population displayed an important 'inertia', so that over-exploitation was detected with some delays. Together with the presence of pseudo-cycles, this makes difficult to detect overfishing and depletion risks. SKJ displayed a contrasting situation. Its recruitment remained at its maximum (Table 2), and its SSB has declined (from 850000 to 250000 tonnes), but was still largely sufficient to avoid any recruitment overfishing (Fig. 6). Finally, the SKJ yields increased from about 135000 tonnes at the beginning to 300000 tonnes at the end of the fishing period (i.e., when the simulated BFT population collapsed). The year-to-year fluctuations in the SKJ yields were, however, larger at the end of the fishing period (Fig. 6) and the yields reached a plateau at around time $\mathrm{t}=150$.

Interaction of age-at-maturity and fishing selectivity

All the scenarios converged to the same conclusion: SKJ sustained high F, but BFT did not. As F increased, the SSB of BFT declined much more than the SSB of SKJ, so that recruitment overfishing and collapse of the BFT population could occur. We hypothesised that this result could reflect the combination of the age-at-maturity with the fishing mortality pattern. In the three scenarios, fishing mortality started at age 1, so that 3.5 BFT juvenile classes were fished against 0.5 for SKJ. The BFT spawning stock was then fed by a relatively lower number of new spawners than SKJ. We, thus, modified the fishing selectivity in order to target only adults for both species ( $\mathrm{F}=0$ until age 1.5 and age 4 for SKJ and BFT, respectively). 
According to this new fishing pattern, we ran again the 3 different fishing scenarios one hundred times for both species (summary in Table 3). In contrast to the previous simulations, recruitment overfishing or collapse of the simulated BFT population was no more longer detected, either in scenario 2 or 3, as indicated by the value of recruitment which remained at its maximum (Table 3, see also Fig. 7). In scenario 3, the SSB of BFT fell to a rather low level at the end of the fishing period (around 50000 tonnes, Fig. 7), but was still high enough to sustain very high fishing mortality (up to $\mathrm{F}=1.6$, whereas $\mathrm{BFT}$ attained previously its limit of sustainability earlier, at around $\mathrm{F}=0.8$ ). The BFT yields were about two times higher than previously (mean at around 51600 tonnes against 27800 , Tables 2 and 3), and only decreased slightly from the beginning to the end of the fishing period, from 60000 to 40000 tonnes (Fig. 7). Here also, the combination of variations in the recruitment and the long life span could lead to strong variations in SSB and yields, with an alternation of high (from 70000 to 100000 tonnes) and low catch periods (20 000 to 40000 tonnes, Fig. 7). For SKJ, this new fishing pattern lead to a higher level in the SSB and a slightly lower level in the yields (Table3, Fig. 7). Throughout the fishing period, the yields continued to increase, following the increasing shape of the F pattern (Fig. 7).

There is thus a clear interaction between the age-at-maturity and the fishing selectivity. If juveniles are not fished, both species are able to sustain very high F and BFT does not display any sign of recruitment overfishing or collapse.

\section{Discussion}

\section{Life history traits of tropical versus temperate tunas}

Life history traits of tropical and temperate tunas and tuna-like species are clearly divergent. On the one hand, tropical tunas (SKJ, LTA and YFT) are characterised by short to medium size, rapid growth, early age-at-maturity, continuous spawning through the year and short life span. Therefore, these species display a rapid turnover of their population, so that they could be classified as ' $r$ selected' species (Begon et al., 1996, pp. 552-5, see also Au, 1986). On the other hand, temperate tunas display opposite life history traits, i.e., large size, slow growth, late age-at-maturity, short 
spawning season and long life span. These populations display a slow turnover and present some characteristics similar to the 'K-selected' species (Begon et al., 1996). Tropical tunas live and reproduce in warm waters which are commonly considered to be more stable than temperate or cold waters. From a theoretical point of view, there is, thus, a conflict with the $\mathrm{r} / \mathrm{K}$ concept, which predicts 'r-selected' species in a variable environment and 'K-selected' species in stable habitat. However, the r/K concept has often been refuted (Begon et al., 1996, pp. 555), and could be insufficient to explain the population dynamics of tunas. For instance, it ignores important features related to the physiological ecology of these species (Bard et al., 1998; Sharp, 1978). All tunas and tuna-like species need warm waters for reproduction and larval growth (around $24^{\circ} \mathrm{C}$ for tuna larvae, Nishikawa et al., 1985). As a consequence, the tropical waters provide an optimum habitat for tunas, in term of reproduction and growth, that allow an opportunistic strategy.

Conversely, SBF and BFT only reproduce in warm waters but live in temperate to cold waters. Longhurst (1999) recently suggested that reproduction could be the ecological key factor for fish from temperate and cold seas, because of a higher risk of starvation for larvae and young juveniles. Thus, one might argue that temperate tunas have partially resolved this difficulty (because of physiological constraints), by means of yearly reproductive migrations into warmer and more stable environments. However, spawning duration and frequency are much shorter for temperate than tropical tunas. Therefore, the probability of a stable recruitment remains higher for tropical tunas (an hypothesis already proposed by Fonteneau, 1992) and could explain some of the differences in life history traits between tropical and temperate tunas.

\section{Life history traits and exploitation}

Without fishing activity, both simulated populations showed variations in their SSB and yields, resulting from noise in the recruitment. BFT, however, displayed more conspicuous low frequency fluctuations, because of the combination of variations in the recruitment and long life span. Given a fishing mortality starting at age 1, the simulations indicated that: (i) as F increases, the decline in the spawning stock was relatively faster for BFT than SKJ, (ii) SKJ yields were always much larger than 
those of BFT, (iii) risks of recruitment overfishing and collapse were important for BFT, but nil for SKJ (in the range of our scenarios), (iv) there was more variability in SSB and yields of BFT than of SKJ, because of conspicuous pseudo-cycles in the simulated BFT population, (v) these pseudo-cycles induced a periodicity of about 20 years of high and low catches, (vi) which blurred the decline in the yields when the population is over-exploited, so that the crash of the BFT population occurred suddenly. At a first sight, these results would validate the hypothesis stating that SKJ can support higher levels of fishing mortality than BFT.

Points i) and iii) could be related to the fact that the maximum sustainable yield F levels are rarely greater than M. In order to verify this, we repeated the simulations by considering fishing scenarios with F levels scaled to M. Assuming an exponential scenario, with F going from 0.5M to 10M, both simulated SKJ and BFT populations collapsed because of recruitment overfishing at t 200 for BFT and t 220 for SKJ (when F 5M, Fig. 8). This result (as simulations with constant F/M and step-bystep F/M) would indicate that the limit of exploitation is around the same F/M for both SKJ and BFT. As fast growing species (SKJ) generally support higher M than slow growing ones (BFT), the former should therefore support higher absolute F than the latter. Note that the collapse of SKJ appeared suddenly, after a continuous period of increasing yields (whereas BFT yields mostly decreased). The SKJ collapse was quicker than that of BFT because of the smaller number of age classes. Total SKJ yields were, however, still about 5 to 10 times higher than those of BFT. Whether equal F or equal $\mathrm{F} / \mathrm{M}$ are considered, SKJ is always more productive than BFT because of the more rapid turnover of its population.

\section{Life history traits and age-specific selectivity patterns}

There is also a clear interaction between age-at-maturity and fishing selectivity. If only adults were targeted, the simulated BFT population did not display any sign of recruitment overfishing or collapse and both species were able to sustain high F. To understand these results, one has to consider the interaction between three variables: (i) the life span (number of age classes), (ii) the 
selectivity pattern, and (iii) the growth in weight. As BFT has 4.5 juvenile classes, an exploitation starting at age 1 implies an important mortality throughout the juvenile stages, which subsequently induces an important risk of depletion of the spawning stock ( $\mathrm{F}=0.5$ implies that less than $10 \%$ of the recruits reach age 5). This situation does not occur for SKJ, as the exploitation of juveniles takes place during a very short period. Furthermore, there is a large difference in weight between juveniles and adults for BFT, but not for SKJ (mean weight of a juvenile is $\sim 0.8 \mathrm{~kg}$ for SKJ and $\sim 10 \mathrm{~kg}$ for BFT; that of an adult is $\sim 3 \mathrm{~kg}$ for SKJ and $\sim 200 \mathrm{~kg}$ for BFT). From a fishery point of view, the gain from letting the recruitment feed the spawning stock is, thus, greater for BFT than for SKJ. Our results even showed that a moderate exploitation of juvenile SKJ (from age 1) allows a substantial increase of the yields without any additional risk for the population (but $\mathrm{F}_{\max }$ would then be reached at a lower effort).

We also ran simulations with recruitment forced to zero during a few succeeding years. As expected, a long life span made the BFT population well adapted to risks of recruitment failures, whereas SKJ was not. BFT could easily support 10 years of recruitment forced to zero, whereas the SKJ dynamics was disrupted if the period with no recruitment persisted for more than 2 years (and the simulated population collapsed when it exceeded 4 years). However, the conditions that could lead to such failure in SKJ recruitment are unlikely, because this species spawns several times per year over all the equatorial Atlantic and lives and reproduces in rather stable environments. These results confirm that the dynamical features of tropical tunas populations are mainly determined by a continuous recruitment and a rapid juvenile growth, i.e., an opportunistic strategy which is appropriate for a tuna in warm waters (see above). Conversely, temperate tunas, such as BFT, are rather resistant to recruitment failure, because of their long life span and the numerous classes of spawners. For these species, the core of the dynamics is related to the reserve that constitutes its spawning stock, i.e., a conservative strategy adapted to a colder and more variable environment (e.g., Longhurst, 1998). 


\section{The actual fishing activity}

From a theoretical point of view, an optimal exploitation strategy would be to target only spawners for BFT and to target both juveniles (moderately) and spawners for SKJ. Actual fishing mortality of SKJ and BFT populations appear at a high level and both species are suspected to have been overexploited for a few years (Anonymous, 1999a; 1999b). It remains, however, difficult, to assert or to deny overfishing, because of a lack of data and information on the biology and ecology of the species (Fonteneau et al., 1998; Fromentin, 1999). Fishing selectivity patterns are, nonetheless, well known for both species (Anonymous, 1999). For SKJ, catches used to be mainly constituted by fish from 1 to $4 \mathrm{~kg}$, i.e., individuals from 1 to 3 years old. For BFT, the highest F were estimated at ages 2 and 3 (i.e., juveniles of about 10 to $25 \mathrm{~kg}$ ), then for ages $8+$ (i.e., adults heavier than $120 \mathrm{~kg}$ ). The actual exploitation pattern is, thus, closer to the scenarios where F starts at age 1 for both species than those where only adults would be fished. If the real F's are of similar amplitude for both species, this means that BFT is, in the present situation, more vulnerable to exploitation than SKJ.

There may be, furthermore, a non-negligible risk of recruitment overfishing and collapse of the BFT population of the East Atlantic and Mediterranean, if the fishing mortality really reached the high values estimated by the scientists of the International Commission for the Conservation of Atlantic Tunas (ICCAT, Anonymous, 1999a). This risk could be further difficult to detect because of the presence of natural long-term fluctuations in SSB and yields, a feature recently described for the Atlantic bluefin tuna from the historical tuna trap data by Fromentin et al. (in press) and which is well known for several fish populations, such as the Atlantic cod (e.g., Cushing, 1982; Dickson and Brander, 1993; Fromentin et al., 1997; 1998), the Atlantic and Pacific herring, anchovy and sardine (e.g., Alheit and Hagen, 1997; Baumgartner et al., 1992; Southward et al., 1988) or the Pacific salmon (e.g., Beamish and Bouillon, 1993). Moreover, any risk of overfishing would be further detected with a delay, because of the important 'inertia' of the BFT population resulting from its numerous age-classes. In case of over-exploitation, our simulations showed that ICCAT should reinforce the current measures on the size limit of BFT in order to limit fishing of juveniles as much as possible. This would permit a better rebuilding of the SSB as well as a higher productivity of the 
fisheries. Measures on the size limit appear, however, less critical for skipjack, even if these populations were over-exploited. The last simulations showed that the collapse of SKJ population is very rapid as soon as the limit of sustainability is exceeded (a limit partially blurred by the continuously increasing trend of the yields). It appears, therefore, particularly important to define relevant biological or fisheries reference points for SKJ. In conclusion, when management procedures can be roughly stated at a single species level (which is not always the case, see Gislason, 1999), our results stress the importance of taking account of differences in life history traits.

\section{Acknowledgements}

Thanks are due to Dr. Papa Kébé (ICCAT, Madrid) who provided length and tag data of Atlantic tunas and tuna-like species, to Dr. François Gauthiez who gave helpful advice on statistical aspects and to Dr. D. Ardill who revised the English. The European program 'STROMBOLI' (DG XIV, contract 99/022) gave financial support to this study. 


\section{References}

Alheit, J., Hagen, E., 1997. Long-term climate forcing of European herring and sardine populations. Fish. Oceanogr. 6, 1054-6006.

Alves, A., de Barros, P., Pinho, M.R., 1998. Age and growth of bigeye tuna, Thunnus obesus, captured in Madeira archipelago. ICCAT scient. pap. 48, 277-283.

Amorim, A.F., Arfelli, C.A., Antero-Silva, J.N., Fagundes, L., Costa, F.E.S., Assumpçao, R., 1998. Blue marlin (Makaira nigricans) and white marlin (Tetrapturus albidus) caught off the Brazilian coast. ICCAT scient. pap. 47, 163-172.

Anonymous, 1996. Report of the final meeting of the ICCAT Albacore research program. ICCAT scient. pap. 43, 1-116.

Anonymous, 1997. 1996 SCRS detailed report on bluefin tuna. ICCAT scient. pap. 46, 1-301.

Anonymous, 1998a. 1997 SCRS detailed report on bigeye tuna. ICCAT scient. pap. 48, 109-176.

Anonymous, 1998b. Report of the third ICCAT billfish workshop. ICCAT scient. pap. 47, 1-128.

Anonymous, 1999a. 1998 SCRS detailed report on bluefin tuna. ICCAT scient. pap. 49(2), 1-191.

Anonymous, 1999b. 1998 SCRS detailed report on skypjack. ICCAT scient. pap. 49(3), 123-158.

Antoine, L., Cayré, P., Mendoza, J., 1982. Etude de la croissance du listao (Katsuwonus pelamis) de Atlantique au moyen des rayons de la nageoire dorsale. Mise au point d'une méthodologie - Résultats préliminaires. ICCAT scient. pap. 17, 195-208.

Arocha, F., Lee, D.W., 1996. Maturity at size, reproductive seasonality, spawning frequency, fecundity and sex ratio in swordfish from the Northwest Atlantic. ICCAT scient. pap. 45, 350-357.

Au, D.W.K., 1986. Skipjack population dynamics; is it qualitatively different from that of other tropical tunas? In: Symons, P.E.K., Miyake, P., Sakagawa, G.T., (Eds), Proceedings of the ICCAT conference on the international skipjack year program. Costero de Canarias, 21-29 June 1983. ICCAT symp. pp. 189-197. 
Baglin, R.E., 1977. Maturity, fecundity and sex composition of white marlin (Tetrapturus albidus). ICCAT scient. pap. 6, 408-416.

Baglin, R.E., 1979. Sex composition, length-weight relationship and reproduction of the white marlin (Tetrapturus albidus) in the Western North Atlantic ocean. Fish. Res. 76, 919-925.

Bard, F.X., 1981. Le thon germon Thunnus alalunga (Bonaterre 1788) de l'océan atlantique. Thèse de Doctorat d'Etat, Université Pierre et Marie Curie, Paris.

Bard, F.X., 1984. Croissance de l'Abacore (Thunnus albacores) Atlantique d'après les données de marquages. ICCAT scient. pap. 20, 104-116.

Bard, F.X., Capisano, C., 1991. Actualisation des connaissances sur la reproduction de l'albacore (Thunnus alalunga) en océan atlantique. ICCAT scient. pap. 36, 182-204.

Bard, F.X., Compean-Jimenez, G., 1980. Conséquences pour l'évaluation du taux d'exploitation du germon (Thunnus alalunga) nord atlantique d'une courbe de croissance déduite de la lecture des sections de rayons épineux. ICCAT scient. pap. 9, 365-375.

Bard, F.X., Josse, E., Bach, P., 1998. Habitat et écophysiologie des thons : Quoi de neuf depuis 15 ans? ICCAT scient. pap. 50, 319-342.

Bard, F.X., Kume, S., Antoine, L., 1983. Données préliminaires sur la croissance, les migrations et la mortalité du listao (Katsuwonus pelamis) en Atlantique est obtenues à partir du marquage. ICCAT scient. pap. 18, 271-294.

Baumgartner, T.R., Soutar, A., Ferreira-Bartrina, V., 1992. Reconstruction of the history of Pacific sardine and northern anchovy populations over the past two millennia from sediments of the Santa Barbara Basin. CalCOFI Rep. 33, 24-40.

Beamish, R.J., Bouillon, D.R., 1993. Pacific salmon production trends in relation to climate. Can. J. Fish. Aquat. Sci. 50, 1002-1016.

Begon, M., Harper, J.L., Townsend, C.R., 1996. Ecology (Third ed.). Blackwell Science. Oxford. Beverton, R.J.H., Holt, S.J., 1957. On the dynamics of exploited fish populations. Fish. Invest. London Ser. 2, 19. 
Box, G.E.P., Jenkins, G.M., 1976. Time series analysis forecasting and control. Holden-Day, San Francisco.

Capisano, C., 1989. Le voilier de l'Atlantique est, Istiophorus albicans (Latreille, 1804) : Quelques aspects de la biologie et de la reproduction. ICCAT scient. pap. 30, 392-430.

Capisano, C., Fonteneau, A., 1991. Analyse des fréquences de longueur, du sex-ratio et des zones de reproduction de l'albacore, Thunnus albacores, de l'Atlantique. ICCAT scient. pap. 36, 241-279.

Caton, A.E., 1991. Review of aspects of southern bluefin tuna biology, population and fisheries. In: Deriso, R.B., Bayliff, W.H., (Eds), World meeting on stock assessment of bluefin tunas: strengths and weaknesses. IATTC J. Spec. Rep. 7: 181-350.

Cayré, P., 1981. Maturité sexuelle, fécondité et sex ratio du listao (Katsuwonus pelamis) des côtes d'Afrique de l'Ouest $\left(20^{\circ} \mathrm{N}-0^{\circ} \mathrm{N}\right)$ étudiés à partir des débarquements thoniers (1977 à 1979), au port de Dakar, Sénégal. ICCAT scient. pap. 15, 135-149.

Cayré, P., Amon Kothias, J.B., Stretta, J.M., Diouf, T., 1988. Biologie des thons. In: Fonteneau, A., Marcille, J. (Eds) Ressources, pêche et biologie des thonidés tropicaux de l'Atlantique centre-est, FAO Doc. Tech. Pêches, Rome. pp. 157-268.

Cayré, P., Diouf, T., 1981. Croissance de la thonine, Euthynnus alletteratus (Rafinesque 1881) établie à partir des coupes transversales du premier rayon de la nageoire dorsale. ICCAT scient. pap. 15, 337345.

Cayré, P., Diouf, T., 1984. Croissance du thon obèse (Thunnus obesus) de l'Atlantique d'après les résultats de marquage. ICCAT scient. pap. 20, 180-187.

Cayré, P., Farrugio, H., 1986. Maturité sexuelle du listao (Katsuwonus pelamis) capturé aux Açores de 1980 à 1982. In: Symons, P.E.K., Miyake, P., Sakagawa, G.T., (Eds), Proceedings of the ICCAT conference on the international skipjack year program. Costero de Canarias, 21-29 June 1983. ICCAT symp. pp. 252-272.

Cayré, P., Laloë, F., 1986. Relation poids-longueur du listao (Katsuwonus pelamis) de l'océan Atlantique. In: Symons, P.E.K., Miyake, P., Sakagawa, G.T., (Eds), Proceedings of the ICCAT 
conference on the international skipjack year program. Costero de Canarias, 21-29 June 1983. ICCAT symp. pp. 335-340.

Champagnat, C., Pianet, R., 1974. Croissance du patudo (Thunnus obesus) dans les régions de Dakar et de Pointe-Noire. ICCAT scient. pap. 2, 141-144.

Chur, V.N., Grudinin, V.B., Zharov, V.L., 1980. Data on length-age composition and gonad maturity stages of skipjack (Katsuwonus pelamis) of the eastern tropical Atlantic. ICCAT scient. pap. 9, 245254.

Clay, D., 1991. Atlantic bluefin tuna (Thunnus thynnus thynnus (L.)): a review. In: Deriso, R.B., Bayliff, W.H., (Eds), World meeting on stock assessment of bluefin tunas: strengths and weaknesses. IATTC J. Spec. Rep. 7: 89-180.

Coan, A., 1976. Length, weight and age conversion tables for Atlantic tunas. ICCAT scient. pap. 5, 6466.

Cort, J.L., 1991. Age and growth of the bluefin tuna Thunnus thynnus (L.) of the Northeast Atlantic. ICCAT scient. pap. 35, 214-230.

Cushing, D.H., 1982. Climate and fisheries. Academic Press, London.

Cushing, D.H., 1995. Population production and regulation in the sea: a fisheries perspective. Cambridge University Press, Cambridge.

Dickson, R.R., Brander, K., 1993. Effects of a changing windfield on cod stocks of the North Atlantic. Fish. Oceanogr. 2, 124-153.

Diouf, T., 1991. Les pêcheries thonières d'albacore de l'Atlantique. Bilan de l'évolution durant la période récente. ICCAT scient. pap. 36, 289-325.

Draganik, B., Cholyst, J., 1988. Temperature and moonlight as stimulators for feeding activity by swordfish. ICCAT scient. pap. 27, 305-314.

Ehrardt, N.M., 1991. Review of the age and growth of swordfish (Xiphias gladius) in the Northwestern Atlantic. ICCAT scient. pap. 35, 362-371.

Ehrardt, N.M., Robbins, R.J., Arocha, F., 1996. Age validation and growth of swordfish, Xiphias gladius, in the Northwest Atlantic. ICCAT scient. pap. 45, 358-367. 
Engen, S., Lande, R., 1996. Population dynamic models generating species abundance distributions of the gamma type. J. Theor. Biol. 178, 325-331.

Farber, M.L., 1988. An overview of available information pertinent to interpreting possible stock structure of sworfish in the Atlantic ocean. ICCAT scient. pap. 27, 240-255.

Farrugio, H., 1981. Exploitation et dynamique des populations de thon rouge, Thunnus thynnus (Linné 1758), Atlanto-Méditéranéennes. Thèse de Doctorat d'Etat, Université des Sciences et Techniques du Languedoc, Montpellier.

Fonteneau, A., 1980. Croissance de l'Albacore (Thunnus albacores) de l'Atlantique est. ICCAT scient. pap. 9, 152-168.

Fonteneau, A., 1986. Le modèle global et la dynamique du listao. In: Symons, P.E.K., Miyake, P., Sakagawa, G.T., (Eds), Proceedings of the ICCAT conference on the international skipjack year program. Costero de Canarias, 21-29 June 1983. ICCAT symp. pp. 208-233.

Fonteneau, A., 1992. A comparative study of yellowfin tuna in the Eastern Pacific and in the Eastern Atlantic. IATTC Int. Rep. 22, 1-71.

Fonteneau, A., Gascuel, D., Pallares, P., 1998. Vingt-cinq ans d'évaluation des ressources thonières de l'Atlantique : quelques réflexions méthodologiques. ICCAT scient. pap. 50, 523-561.

Fromentin, J.-M., 1999. Bluefin Tuna stock assessment in the Northeast Atlantic. Problems related to data, methods and knownledge. ICCAT scient. pap. 49, 388-399.

Fromentin, J.-M., Stenseth, N.C., Gjøsæter, J., Bjørnstad, O., Falk, W., Johannessen, T., 1997. Spatial patterns of the temporal dynamics of three gadoids species along the Norwegian Skagerrak coast. Mar. Ecol. Prog. Ser. 155, 209-222.

Fromentin, J.-M., Stenseth, N.C., Gjøsæter, J., Johannessen, T., Planque, B., 1998. Long-term fluctuations in cod and pollack along the Norwegian Skagerrak coast. Mar. Ecol. Prog. Ser. 162, 265278.

Fromentin, J.-M., Myers, R.M., Bjørnstad, O., Stenseth, N.C., Gjøsæter, J., Christie, H., Effects of density-dependent and stochastic processes on the stabilization of cod populations. Ecology, in press. 
Fromentin, J.-M., Fonteneau, A., Farrugio, H., Biological key reference points and natural long-term fluctuations : the case of the Atlantic bluefin tuna. ICCAT scient. pap. in press.

Gabriel, K.R., 1971. The biplot graphical display of matrices with applications to principal component analysis. Biometrika 58, 453-467.

Gislason, H., 1999. Single and multispecies reference points for Baltic fish stocks. ICES J. Mar. Sci. 56, 571-583.

Greenstreet, S.P.R., Spence, F.B., McMillan, J.A., 1999. Fishing effects in northeast Atlantic shelf seas: patterns in fishing effort, diversity and community structure. V. Changes in structure of the North Sea groundfish species assemblage between 1925 and 1996. Fish. Res. 40, 153-183.

Gulland, J.A., 1977. The analysis of data and development of models. In: Gulland, J.A., (Eds), Fish population dynamics, John Wiley and Sons, London. pp. 67-95.

Hilborn, R., Walters, C.J., 1992. Quantitative fisheries stock assessment. Choice, dynamics and uncertainty. Chapman and Hall, New-York.

Hjort, J., 1914. Fluctuations in the great fisheries of northern Europe. Viewed in the light of biological reseach. Rapp. P.-v Réun. Cons. int. Explor. mer 20, 1-228.

Hoey, J., Bertolino, A., 1988. Review of the U.S. fishery for swordfish, 1978 to 1986. ICCAT scient. pap. 27, 267-282.

Jennings, S., Greenstreet, S.P.R., Reynolds, J.D., 1999. Structural changes in a exploited fish community: a consequence of differential fishing effects on species with contrasting life histories. J. Anim. Ecol. 68, 617-627.

Jennings, S., Reynolds, J.D., Mills, S.C., 1998. Life history correlates of responses to fisheries exploitation. Proc. Roy. Soc. London Ser. B 265, 333-339.

Legendre, P., Legendre, L., 1998. Numerical ecology (Second English Ed.). Elsevier, Amsterdam.

Longhurst, A., 1998. Cod: perhaps if we all stood back a bit? Fish. Res. 38, 101-108.

Longhurst, A., 1999. Does the benthic paradox tell us something about surplus production models? Fish.

Res. 41, 111-117. 
Mather, F.J., Mason Jr, J.M., Jones, A., 1995. Historical document: life history and fisheries of Atlantic bluefin tuna. NOAA Technical Memorandum N.M.F.S., Miami.

Matlab, 1999. Matlab 5.3, the language of technical computing. MathWorks Inc, Natick.

May, R.C., 1974. Larval mortality in marine fishes and the critical period concept. In: Blaxter, J.H.S. (Eds), The early life history of fish. Springler-Verlag, New-York. pp. 3-19.

Mejuto, J., Garcia, B., 1997. A preliminary analysis of gonadal indices of the swordfish (Xiphias gladius) in the Atlantic ocean. ICCAT scient. pap. 46, 336-344.

Myers, R.A., Cadigan, N.G., 1993. Density-dependence juvenile mortality in marine demersal fish. Can. J. Fish. Aquat. Sci. 50, 1576-1590.

Nishikawa, Y., Honma, M., Ueyanagi, S., Kikawa, S., 1985. Average distribution of larvae of oceanic species of scombroid species, 1956 - 1981. Bull. Far Sea Fish. Lab. S. Series 12.

Ovchinnikov, V.V., Grudtsev, M.E., Kholodkova, S.V., 1980. Length-age composition of the tropical Atlantic swordfishes (Xiphias gladius, L.). ICCAT scient. pap. 9, 620-623.

Pallares, P., Fonteneau, A., Nordstrom, V., Delgado de Molin, A., Carlos Santana y Javier Ariz, J., 1998. Anaysis de la capturas de atunes asociados a objetos flotantes, efectuadas por las flotas de cerco en el Océano Atlantico. ICCAT scient. pap. 50, 449-474.

Porter, J.M., Smith, S.C., 1991. Literature review of differential growth and mortality in Atlantic swordfish, Xiphias gladius. ICCAT scient. pap. 35, 445-448.

Ricker, W.E., 1954. Stock and recruitment. J. Fish. Res. Bd. Can. 11, 559-623.

Sharp, G.D., 1978. The physiological ecology of tunas. Academic Press, London.

Sokal, R.R., Rohlf, F.J., 1995. Biometry. W.H. Freeman and Co, New-York.

Southward, A.J., Boalch, G.T., Maddock, L., 1988. Fluctuations in the herring and pilchard fisheries of Devon and Cornwall linked to change in climate since the 16th century. J. mar. Biol. Ass. U.K. 68, 423-445.

Souza, R.C., Lessa, R., Hazin, F., 1994. First observations on reproductive biology of billfishes (Tetrapturus albidus, Istiophorus albicans and Tetrapturus pfluegeri) in southwestern equatorial Atlantic (Brazil). ICCAT scient. pap. 42, 329-334. 
S-Plus, 1997. S-plus 4, guide to statisticics. MathSoft Inc, Seattle.

Tiews, K., 1978. On the disapperance of bluefin tuna in the North Sea and its ecological implications for herring and mackerel. Rapp. P.-v. Réun. Cons. int. Explor. Mer 172, 301-309.

Weber, E., 1980. An analysis of Atlantic bigeye tuna (Thunnus obesus) growth. ICCAT scient. pap. 9, 303-307.

Wei, W.W.S., 1990. Times series analysis. Univariate and multivariate methods. Addison Wesley, Redwood City, California.

Note: reports containing ICCAT scientific papers may be directly downloaded or requested at ICCAT Website: http://www.iccat.es/ 


\section{Legends}

Figure 1. Biplot representation of the first two axes of the Principal Component Analysis performed on the life history traits (descriptors) of 10 tunas and tuna-like species (objects). Five descriptors were retained for this analysis: length at maturity (L.Mat), maximum age (Max.Age), juvenile growth (Growth), spawning duration (Spawning) and minimal SST (SST). For the species` acronyms, see text in 'Data section'. The percentage of variance explained by each axis is given in parenthesis and the loadings plots are superimposed on the right bottom of the graph.

Figure 2. The three different patterns of fishing mortality for both SKJ and BFT. Scenario 1: constant $\mathrm{F}$ equal to 0.5 all along the period; scenario 2: $\mathrm{F}$ equal to $0.2,0.5$ and 0.8 during three equal periods and scenario 3: exponential F going from 0.1 to 1.6. Simulations were run over 200 years after a transition period of 50 years that allows a steady state to be reached (equilibrium balanced at a spawning stock biomass equal to 1 million tonnes for all the following simulations).

Figure 3. SKJ and BFT outputs from the simulation modelling without fishing mortality. The time series include the transition period of 50 years (to reach the steady state balanced at a SSB $=1$ million tonnes) during which no random noise was added to the recruitment and, a period of 200 years with random noise in the recruitment. Top graphs: recruitment time series, bottom graphs: spawning stocks biomass time series.

Figure 4. SKJ and BFT outputs from the simulation modelling with scenario 1 (constant fishing mortality of 0.5 during the last 200 years). The first 50 years is the transition period (to reach the steady state balanced at a SSB = 1 million tonnes and during which there is no fishing mortality and no noise in the recruitment). Fishing mortality started at age 1 for both SKJ and BFT (i.e., both juveniles and adults were targeted). Top graphs: recruitment time series, medium graphs: spawning stocks biomass (SSB) time series and bottom graphs: total yields time series. Time series of SSB and yields only start at time $\mathrm{t}=65$ to avoid scaling problems. 
Figure 5. Same as Figure 4 with scenario 2 (step-by-step fishing mortality of 0.2, 0.5 and 0.8 during 3 equal periods of 66 years each).

Figure 6. Same as Figures 4 and 5 with scenario 3 (exponential fishing mortality going from 0.1 to 1.6 over 200 years).

Figure 7. Same as Figure 6 but with a fishing pattern only targeting adults ( $F=0$ until age 1.5 and age 4 for SKJ and BFT, respectively).

Figure 8. Same as Figures 6 but with exponential fishing mortality scaled to M (going from 0.5M to $10 \mathrm{M}$ from age 1 to the last age for both SKJ and BFT). 
Table 1. Life history traits of the 10 selected tunas and tuna-like species. Information on life span (i.e., maximum length, weight and age) as well as minimal SST was derived from catch-at-age and tagging data (see 'Data section'). Growth was computed as: $\frac{\left(\frac{\text { Length }- \text { at }- \text { maturity }}{\text { Maximum-length }}\right) * 100}{\text { Age-at-maturity }}$. Information on spawning duration and maturity was collected from the literature; references: 1 . Alves et al. (1998); 2. Amorim et al. (1998); 3. Anonymous (1996); 4. Anonymous (1997); 5. Anonymous (1998a); 6. Anonymous (1998b); 7. Antoine et al. (1982); 8. Arocha and Lee (1996); 9. Baglin (1977); 10. Baglin (1979); 11. Bard (1981); 12. Bard (1984); 13. Bard and Compean-Jimenez (1980); 14. Bard and Capisano (1991); 15. Bard et al. (1983); 16. Capisano (1989); 17. Capisano and Fonteneau (1991); 18. Caton et al. (1991); 19. Cayré (1981); 20. Cayré and Diouf (1981); 21. Cayré and Diouf (1984); 22. Cayré and Farrugio (1986); 23. Cayré and Laloë (1986); 24. Cayré et al. (1988); 25. Champagnat and Pianet (1974); 26. Chur et al. (1980); 27; Coan (1976); 28. Cort (1991); 29. Diouf (1991); 30. Draganik and Cholyst (1988); 31. Ehrardt (1991); 32. Ehrardt et al. (1996); 33. Farber (1988); 34. Farrugio (1981); 35. Fonteneau (1980); 36. Hoey and Bertolino (1988); 37. Mather et al. (1995); 38. Mejuto and Garcia (1997); 39. Ovchinnikov et al. (1980); 40. Porter and Smith (1991); 41. Souza et al. (1994); 42. Weber (1980).

Table 2. Means of the main statistics computed from one hundred simulations made for each scenario and each species (see text, 'Data section'). Top block: SKJ statistics; medium block: BFT statistics and bottom block: SKJ statistics / BFT statistics ratio.

Table 3. Same as Table 2 with a fishing pattern only targeting adults, for both SKJ and BFT. 


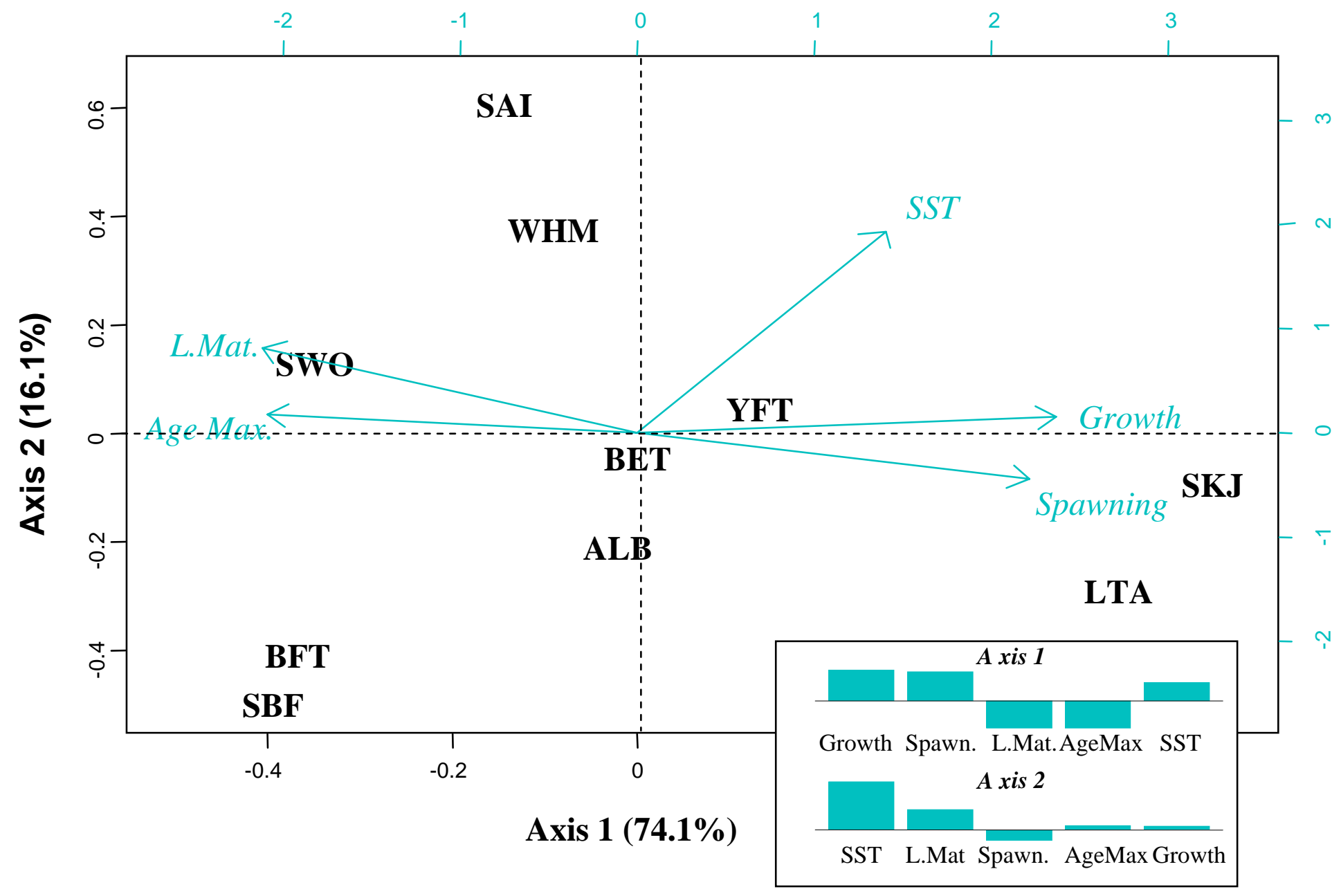

Figure 1 


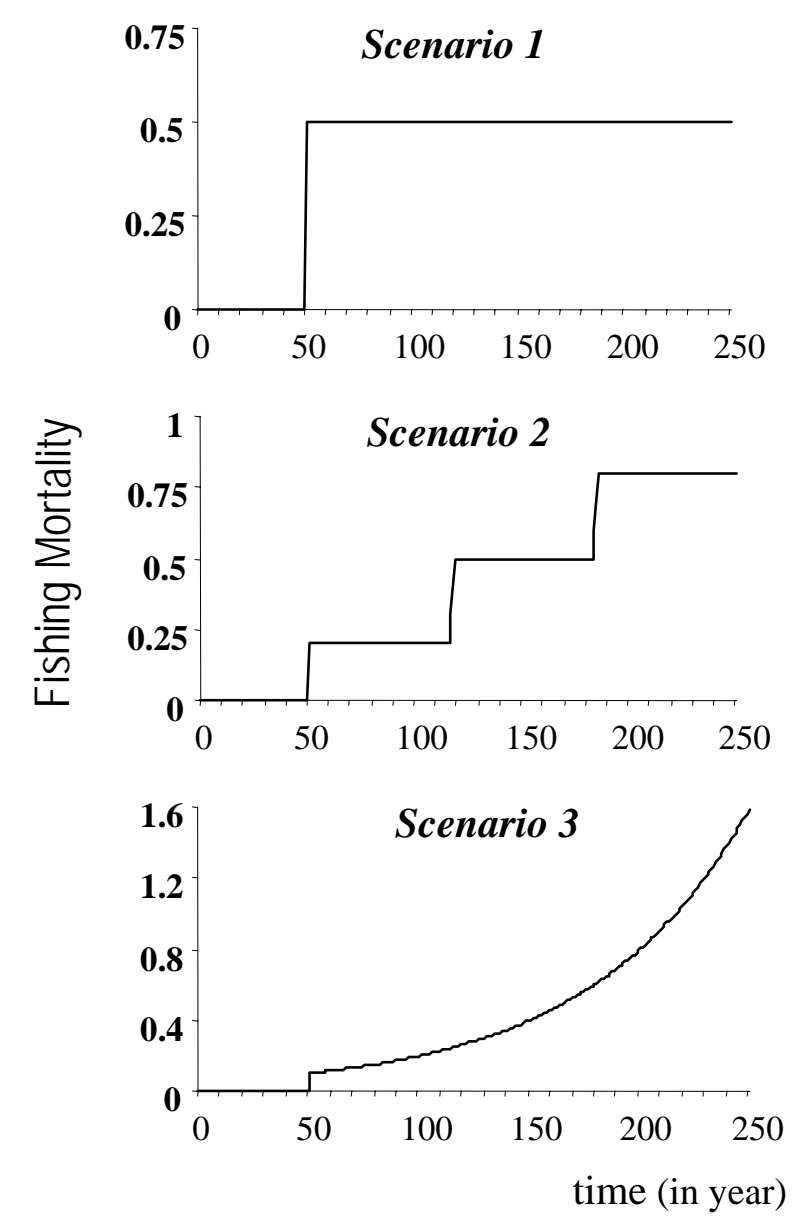

Figure 2 

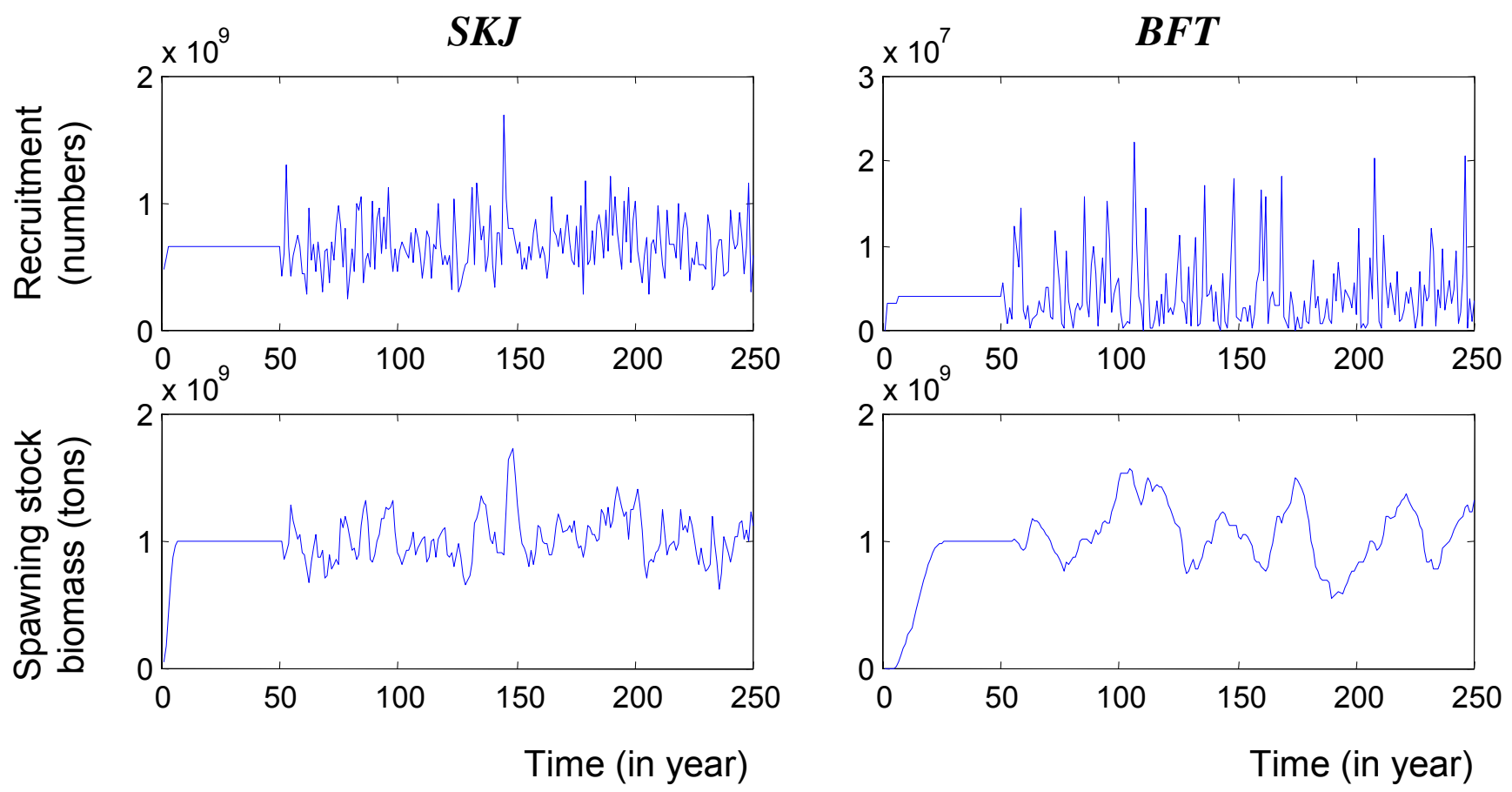

Figure 3 

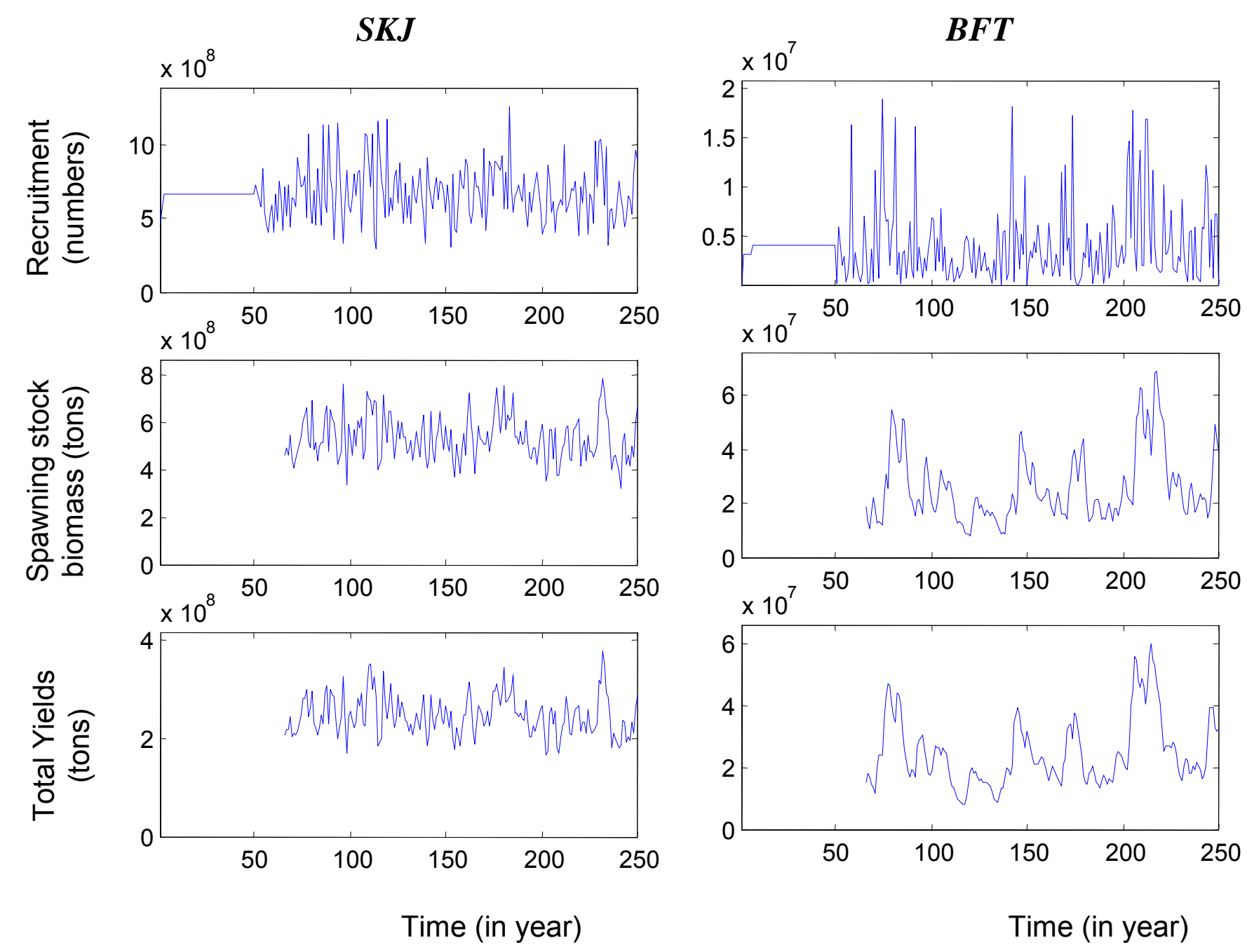

Figure 4 

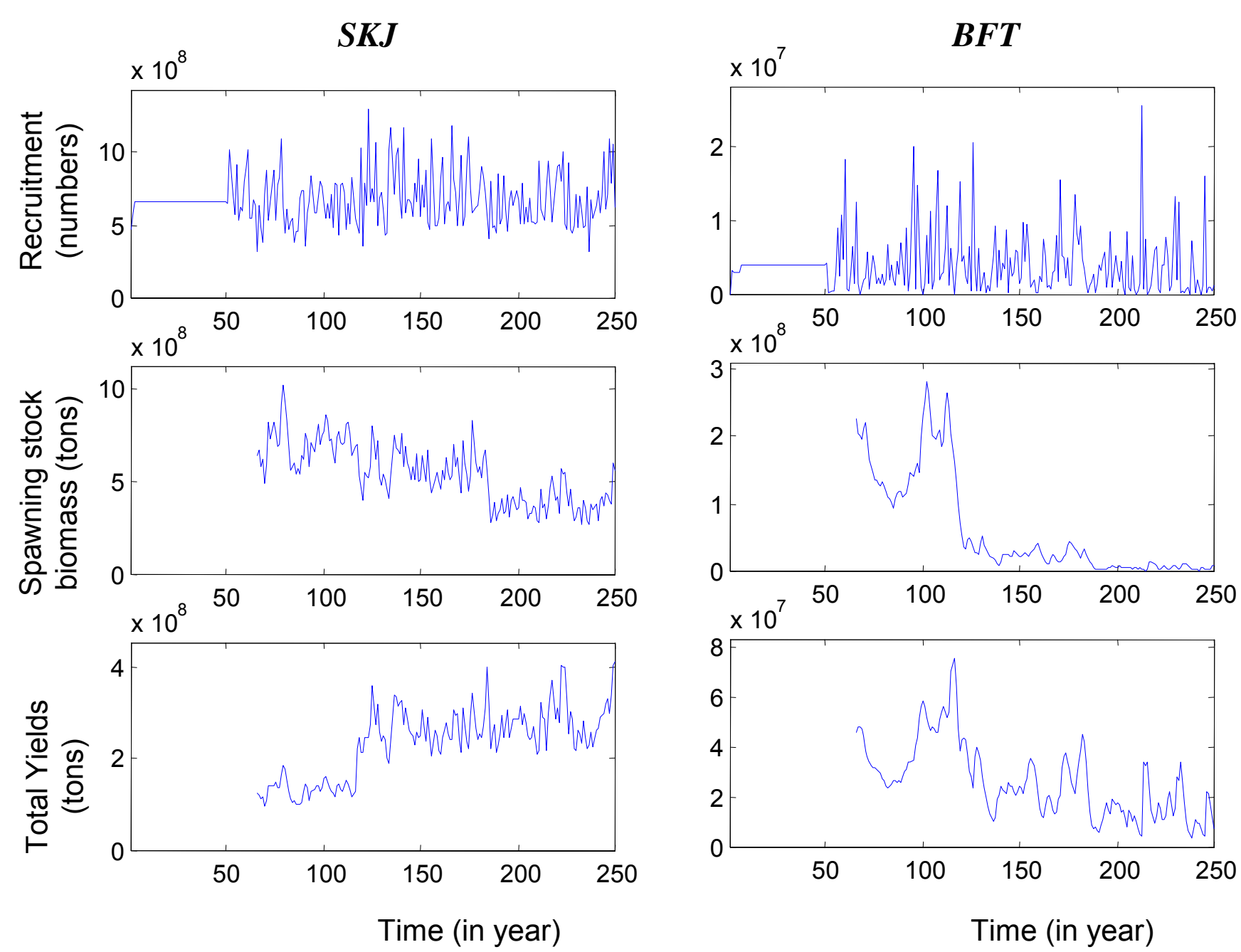

Figure 5 

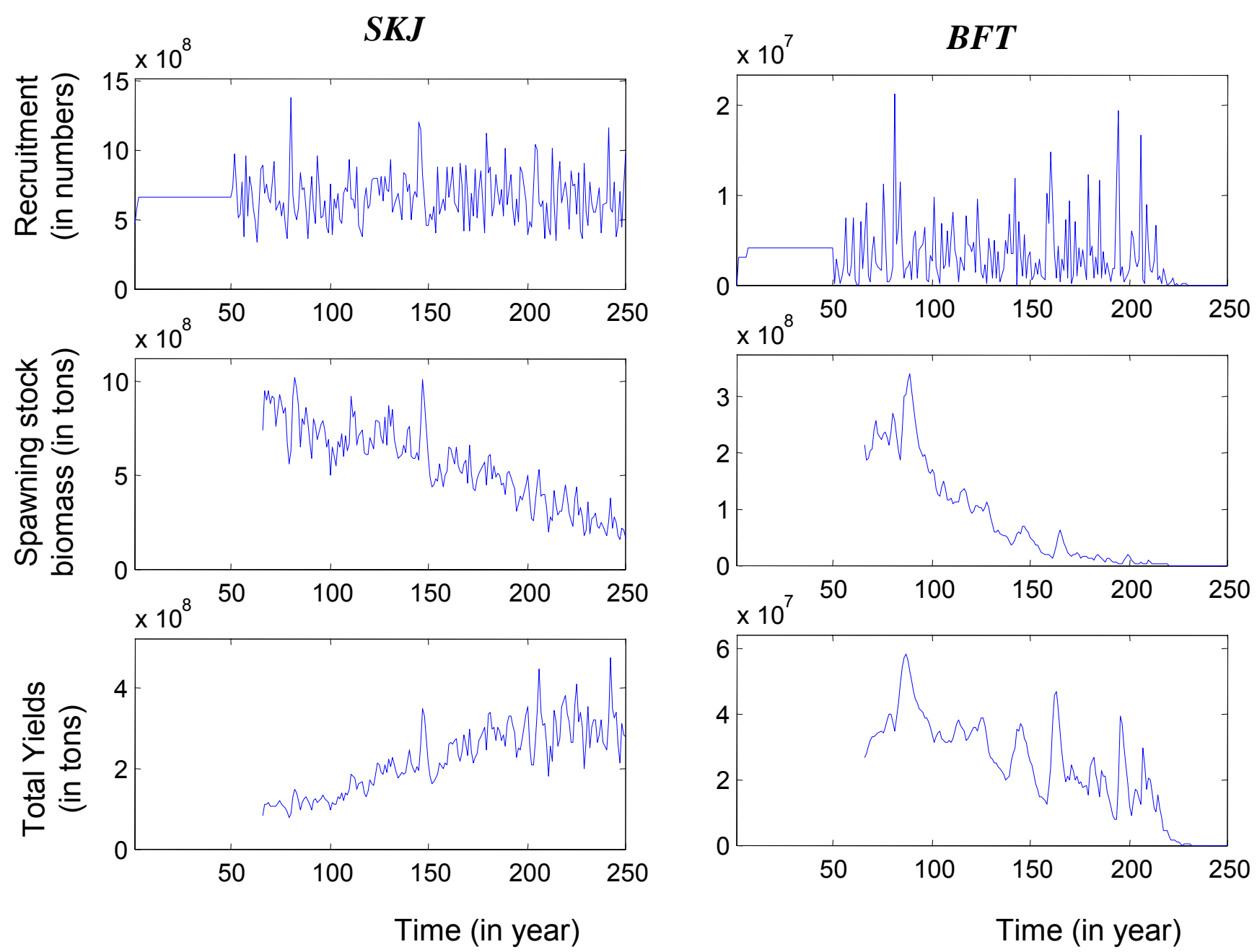

Figure 6 

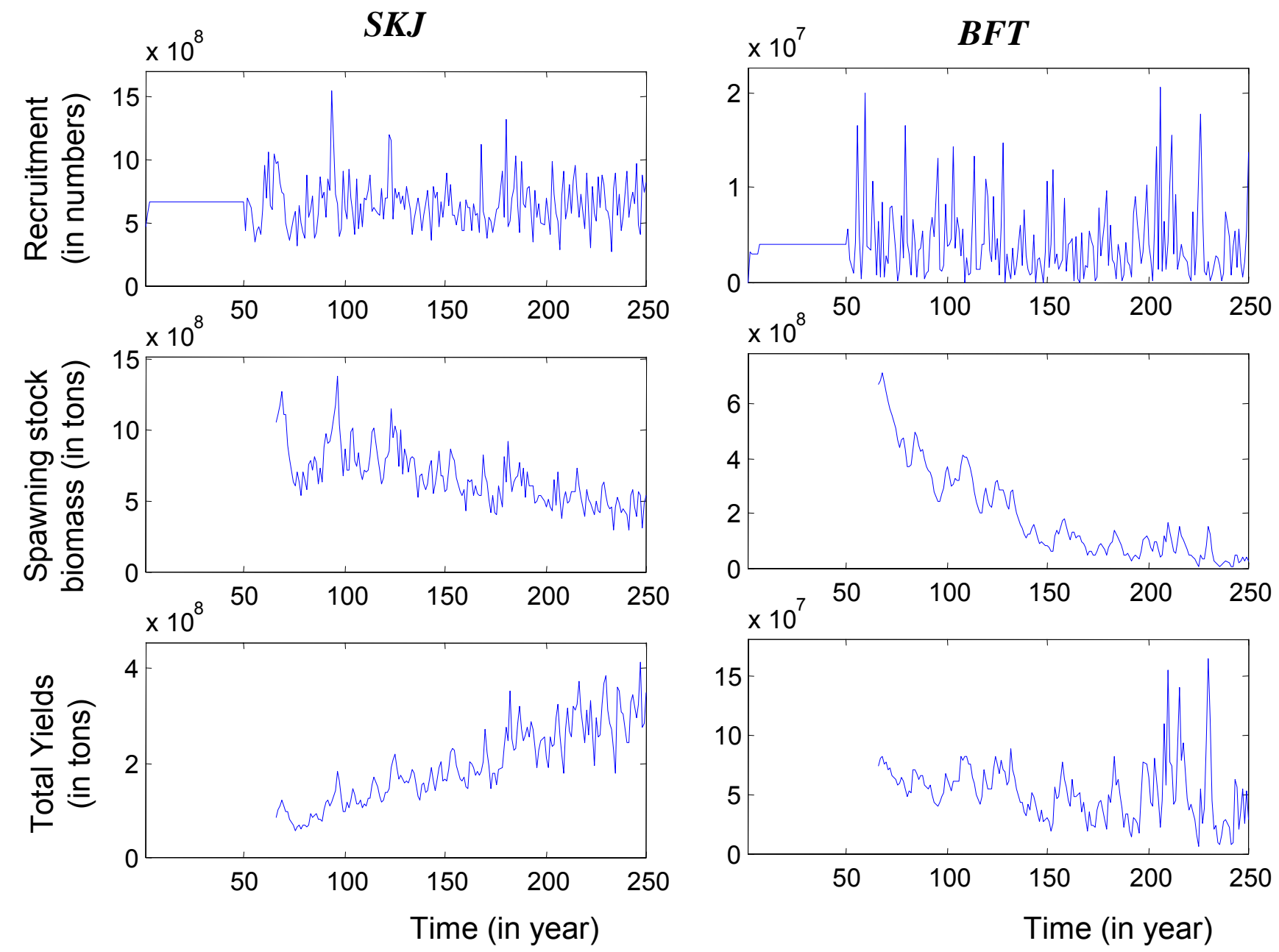

Figure 7 

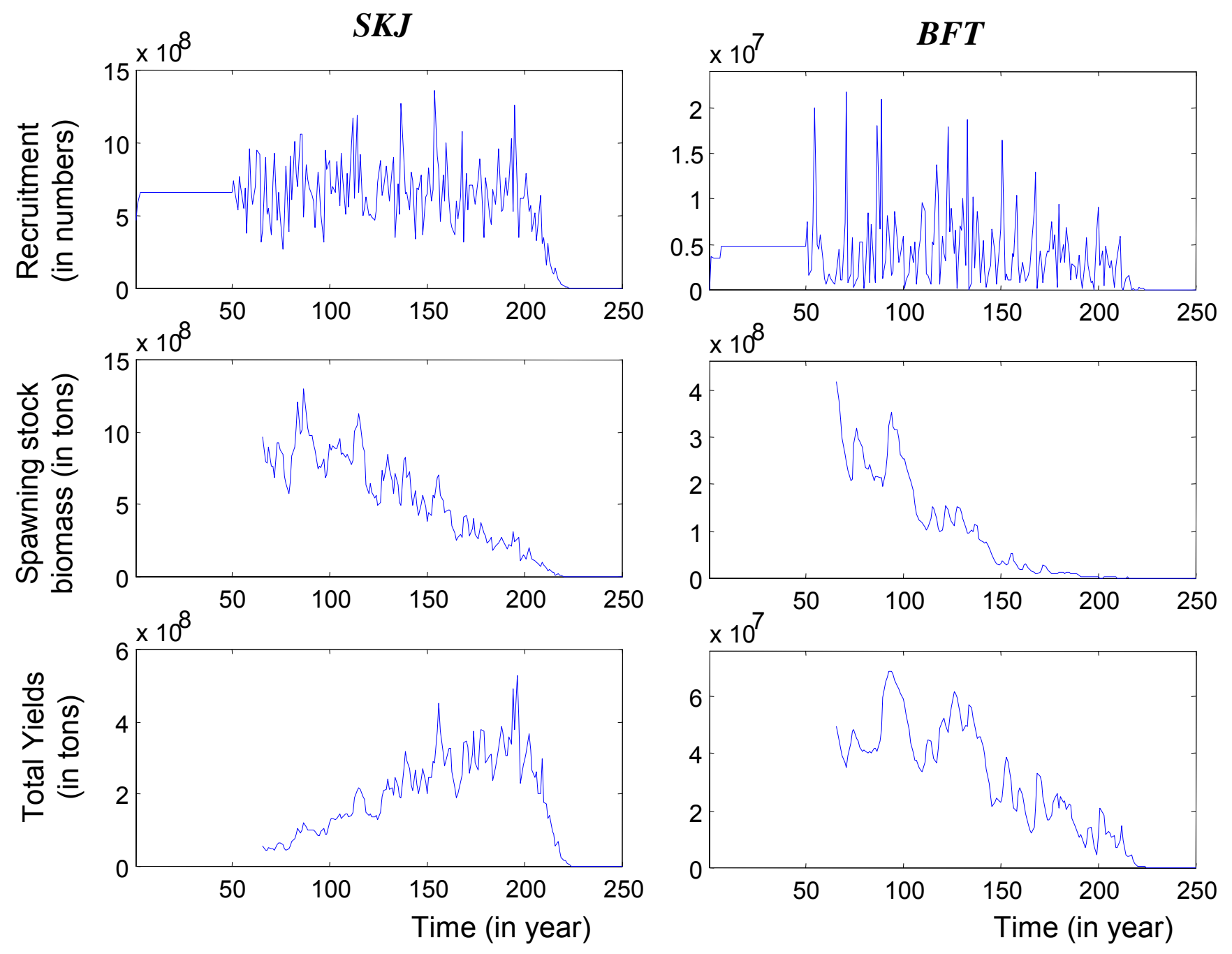

Figure 8 


\begin{tabular}{|c|c|c|c|c|c|c|c|c|c|c|c|c|}
\hline Names & $\begin{array}{c}\text { Acron } \\
\text { ym }\end{array}$ & $\begin{array}{l}\text { Main } \\
\text { latitudinal } \\
\text { range }\end{array}$ & $\begin{array}{l}\text { Spawning } \\
\text { duration } \\
\text { (month/yr) }\end{array}$ & $\begin{array}{l}\text { Length } \\
\text { at } \\
\text { maturity } \\
(\mathrm{cm})\end{array}$ & $\begin{array}{l}\text { Weigth } \\
\text { at } \\
\text { maturity } \\
(\mathrm{kg})\end{array}$ & $\begin{array}{c}\text { Age at } \\
\text { maturity } \\
\text { (year) }\end{array}$ & $\begin{array}{l}\text { Maximum } \\
\text { length } \\
\text { (cm) }\end{array}$ & $\begin{array}{c}\text { Maximum } \\
\text { weigth } \\
(\mathrm{kg})\end{array}$ & $\begin{array}{c}\text { Maximum } \\
\text { age } \\
\text { (year) }\end{array}$ & $\begin{array}{l}\text { Juvenile } \\
\text { growth } \\
\left(\% L \cdot y r^{-1}\right)\end{array}$ & $\begin{array}{l}\text { Minimal } \\
\text { SST } \\
\left({ }^{\circ} \mathrm{C}\right)\end{array}$ & References \\
\hline Skipjack & SKJ & tropical & 12 & 45 & 1.7 & 1.5 & 75 & 23 & 4.5 & 40 & 20 & $\begin{array}{l}7,15,19,20 \\
22,23,24,26\end{array}$ \\
\hline Atlantic little tuna & LTA & tropical & 12 & 42 & - & 1.5 & 85 & 12 & 6 & 32.9 & 18 & 20,24 \\
\hline Yellowfin tuna & YFT & tropical & 6 & 105 & 25 & 2.8 & 170 & 176 & 7.5 & 22.1 & 18 & $\begin{array}{l}12,17,24, \\
27,29,35\end{array}$ \\
\hline Bigeye tuna & BET & $\begin{array}{c}\text { sub- } \\
\text { tropical }\end{array}$ & 3 & 115 & 31 & 3.5 & 180 & 225 & 6 & 18.3 & 16 & $\begin{array}{c}1,5,21,24, \\
25,42\end{array}$ \\
\hline Atlantic sailfish & SAI & $\begin{array}{c}\text { sub- } \\
\text { tropical }\end{array}$ & 2 & 130 & 16 & 3 & 255 & - & 18 & 17 & 22 & $6,16,41$ \\
\hline Atlantic white marlin & WHM & $\begin{array}{c}\text { sub- } \\
\text { tropical }\end{array}$ & 4 & 130 & 20 & 3 & 260 & - & 15 & 16.7 & 20 & $2,6,9,10$ \\
\hline $\begin{array}{c}\text { Albacore } \\
\text { (North Atlantic) }\end{array}$ & ALB & $\begin{array}{c}\text { sub- } \\
\text { tropical \& } \\
\text { temperate }\end{array}$ & 3 & 90 & 15 & 4.5 & 120 & 80 & 9.5 & 16.7 & 15 & $\begin{array}{c}3,11,13,14, \\
27\end{array}$ \\
\hline $\begin{array}{c}\text { Swordfish } \\
\text { (North Atlantic) }\end{array}$ & SWO & $\begin{array}{c}\text { sub- } \\
\text { tropical \& } \\
\text { temperate }\end{array}$ & 3 & 175 & 70 & 5 & 290 & 650 & 17 & 12.1 & 15 & $\begin{array}{c}8,30,31,32 \\
33,36,38 \\
39,40\end{array}$ \\
\hline $\begin{array}{c}\text { Bluefin tuna } \\
\text { (Northeast Atlantic } \\
\text { and. Mediterranean) }\end{array}$ & BFT & temperate & 1.5 & 115 & 27.5 & 4.5 & 295 & 685 & 20 & 8.7 & 11 & $4,28,34,37$ \\
\hline Southern bluefin tuna & SBF & temperate & 2 & 130 & 43 & 8 & 200 & 320 & 19 & 8.1 & 9 & 18 \\
\hline
\end{tabular}

Table 1 


\begin{tabular}{|c|c|c|c|c|c|}
\hline & & No fishing & $\begin{array}{c}\text { Constant } \\
\text { F }\end{array}$ & $\begin{array}{c}\text { Step-by-step } \\
F\end{array}$ & $\begin{array}{c}\text { Exponential } \\
F\end{array}$ \\
\hline \multirow{7}{*}{$S K J$} & Mean(Rec.) & 663750000 & 662180000 & 664790000 & 661230000 \\
\hline & Mean(SSB) & 1000000 & 527110 & 560300 & 574230 \\
\hline & Mean(SSN) & 371950000 & 236150000 & 244670000 & 246480000 \\
\hline & Mean(Yields) & - & 242870 & 225290 & 212200 \\
\hline & CV(Rec.) & 0.29 & 0.29 & 0.29 & 0.29 \\
\hline & $\mathrm{CV}(\mathrm{SSB})$ & 0.15 & 0.18 & 0.32 & 0.39 \\
\hline & CV(Yields) & - & 0.17 & 0.33 & 0.42 \\
\hline
\end{tabular}

\begin{tabular}{|c|c|c|c|c|c|}
\hline \multirow{4}{*}{} & Mean(Rec.) & 4088300 & 4134200 & 3984400 & 3400800 \\
\cline { 2 - 6 } & Mean(SSB) & 1000000 & 32844 & 78034 & 115670 \\
\cline { 2 - 6 } & Mean(SSN) & 6794100 & 445310 & 817810 & 1104200 \\
\cline { 2 - 6 } & Mean(Yields) & - & 27013 & 28862 & 27820 \\
\cline { 2 - 6 } & CV(Rec.) & 0.99 & 0.99 & 1.00 & 1.16 \\
\cline { 2 - 6 } & CV(SSB) & 0.23 & 1.57 & 1.46 & 1.39 \\
\cline { 2 - 6 } & CV(Yields) & - & 0.77 & 0.66 & 0.66 \\
\hline
\end{tabular}

\begin{tabular}{|c|c|c|c|c|c|}
\hline \multirow{4}{*}{ SKJ/BFT } & Mean(Rec.) & 162.4 & 160.2 & 166.9 & 194.4 \\
\cline { 2 - 6 } & Mean(SSB) & 1.0 & 16.0 & 7.2 & 5.0 \\
\cline { 2 - 6 } & Mean(SSN) & 54.7 & 530.3 & 299.2 & 223.2 \\
\cline { 2 - 6 } & Mean(Yields) & - & 9.0 & 7.8 & 7.6 \\
\cline { 2 - 6 } & CV(Rec.) & 0.29 & 0.29 & 0.29 & 0.25 \\
\cline { 2 - 6 } & CV(SSB) & 0.65 & 0.12 & 0.22 & 0.28 \\
\cline { 2 - 6 } & CV(Yields) & - & 0.22 & 0.50 & 0.65 \\
\hline
\end{tabular}

Table 2 


\begin{tabular}{|c|c|c|c|c|c|}
\hline & & No fishing & $\begin{array}{c}\text { Constant } \\
\text { F }\end{array}$ & $\begin{array}{c}\text { Step-by-step } \\
F\end{array}$ & $\begin{array}{c}\text { Exponential } \\
F\end{array}$ \\
\hline \multirow{7}{*}{ SKJ } & Mean(Rec.) & 663750000 & 662320000 & 662550000 & 660980000 \\
\hline & Mean(SSB) & 1000000 & 661850 & 684370 & 694780 \\
\hline & Mean(SSN) & 371950000 & 294490000 & 299340000 & 301000000 \\
\hline & Mean(Yields) & - & 215250 & 199700 & 190090 \\
\hline & CV(Rec.) & 0.29 & 0.29 & 0.29 & 0.29 \\
\hline & $\mathrm{CV}(\mathrm{SSB})$ & 0.15 & 0.18 & 0.24 & 0.27 \\
\hline & CV(Yields) & - & 0.18 & 0.35 & 0.46 \\
\hline
\end{tabular}

\begin{tabular}{|c|c|c|c|c|c|}
\hline \multirow{4}{*}{} & Mean(Rec.) & 4088300 & 4133800 & 4129300 & 4076800 \\
\cline { 2 - 6 } & Mean(SSB) & 1000000 & 122080 & 171880 & 206690 \\
\cline { 2 - 6 } & Mean(SSN) & 6794100 & 1840300 & 2152300 & 2338700 \\
\cline { 2 - 6 } & Mean(Yields) & - & 52787 & 53049 & 51657 \\
\cline { 2 - 6 } & CV(Rec.) & 0.99 & 0.99 & 1.00 & 1.00 \\
\cline { 2 - 6 } & CV(SSB) & 0.23 & 0.52 & 0.80 & 0.87 \\
\cline { 2 - 6 } & CV(Yields) & - & 0.51 & 0.46 & 0.45 \\
\hline
\end{tabular}

\begin{tabular}{|c|c|c|c|c|c|}
\hline \multirow{4}{*}{ SKJ/BFT } & Mean(Rec.) & 162.4 & 160.2 & 160.5 & 162.1 \\
\cline { 2 - 6 } & Mean(SSB) & 1.0 & 5.4 & 4.0 & 3.4 \\
\cline { 2 - 6 } & Mean(SSN) & 54.7 & 160.0 & 139.1 & 128.7 \\
\cline { 2 - 6 } & Mean(Yields) & - & 4.1 & 3.8 & 3.7 \\
\cline { 2 - 6 } & CV(Rec.) & 0.29 & 0.29 & 0.29 & 0.28 \\
\cline { 2 - 6 } & CV(SSB) & 0.65 & 0.35 & 0.30 & 0.31 \\
\cline { 2 - 6 } & CV(Yields) & - & 0.35 & 0.77 & 1.03 \\
\hline
\end{tabular}

Table 3 